\title{
Internationalisation of curriculum at home: Imperatives, opportunities and challenges for allied health education
}

\author{
Srivalli Nagarajan ${ }^{1}$ and Lindy McAllister ${ }^{1}$ \\ srivalli.nagarajan@sydney.edu.au; lindy.mcallister@sydney.edu.au \\ ${ }^{1}$ University of Sydney
}

\begin{abstract}
Preparation of globally competent health graduates who have a good understanding of local and international healthcare is an important goal for allied health education. Internationalisation of Curriculum and Internationalisation at Home strategies are needed to prepare students to work in culturally diverse contexts. A critical review of issues, challenges and future needs in the internationalisation of allied health curricula is the focus of this paper. Current approaches to internationalisation from a range of disciplines are considered and their applicability to allied health courses is discussed. Important challenges for progress on internationalisation goals and integration of internationalisation experiences into allied health curricula are identified. Suggestions for progressing internationalisation of allied health curricula through the formal and informal curriculum are presented. Future research needs that are key to progressing internationalisation goals in allied health education are considered. Important questions that will prompt academics, clinical educators and students to consider how well internationalisation goals are being addressed in allied health education are also raised.
\end{abstract}

Keywords: Allied health, health graduates, Internationalisation of Curriculum, Internationalisation at Home, internationalisation of higher education, global health, crosscultural communication.

\section{Introduction}

Graduates of health degrees, including allied health ${ }^{1}$ graduates, are expected to work in socially and culturally diverse environments and have a good understanding of different cultures, their health behaviours and beliefs (Useh, 2011). Oliver, Jones, Tucker, \& Ferns (2007) state that graduates with international perspectives are able to consider how issues (for example, local healthcare systems or policies) might impact on people in other parts of the world and that graduates with intercultural perspectives are able to consider how issues (such as, one's own cultural beliefs and values) might impact on people from other cultures, for example, in the delivery of healthcare as practicing professionals in their own community. Fuller and Scott (2009) discuss the need for global graduates, that is, graduates who possess skills to work across local as well as international contexts, and the development of job-readiness and employability skills in a global context. To develop such graduates, internationalisation of courses is needed. Allied health practice requires clinicians to interact with patients from diverse cultural backgrounds on a daily basis. This paper makes a case for why internationalisation in allied health is not just desirable but an absolute necessity. In

\footnotetext{
${ }^{1}$ As defined by Services for Australian Rural and Remote Allied Health (Lowe et al., 2007).
} 
this paper a critical review of issues, challenges and future needs in internationalisation of allied health curricula is presented. Approaches to internationalisation from a range of disciplines are reviewed and their applicability to allied health courses is considered. The primary audience for this paper is allied health academics who have responsibility for course design, development and assessment.

There are various social, cultural, academic and economic drivers of internationalisation of university courses. To meet accreditation requirements and prepare workplace needs (McAllister \& Nagarajan, 2015) faculties must prepare culturally competent work-ready ${ }^{2}$ graduates who are able to work with diverse groups of patients. Further, public health issues are increasingly becoming borderless with rapid rates of globalisation (APTA, 2014). Knight (2004) described academic drivers as including international dimensions to research and teaching, international branding, profile and status, and enhancement of academic quality, whereas economic drivers include the need to meet workforce demands for local and global contexts and institutional income generation.

A major challenge to internationalisation of curricula in any discipline is the lack of clarity about what internationalisation means. Hall (2010) undertook a comparison and evaluation of different definitions of the term 'internationalisation'. Hall identified that internationalisation was being used to refer to diverse activities including:

a) an increase in the number of international or foreign students on campus; or

b) the delivery of courses overseas; or

c) international academic mobility for students and lecturers; or

d) the inclusion of international, intercultural or global dimensions in the curriculum and teaching and learning approaches.

Different regional and thematic interpretations (Jones \& De Wit, 2012) along with inconsistency in use of terms such as internationalisation and globalisation are also problematic. Lattanzi and Pechak (2012) state that while globalisation (e.g. the idea of shared global environment or society) highlights common challenges and interconnectedness of societies, internationalisation (e.g. understanding and exploring multiple national identities and contexts) shows us that societies and nations are unique and autonomous and allow us to learn from each other irrespective of the level of development that has occurred in various societies. As a result attempts to develop a shared understanding of what internationalisation entails may become complicated and difficult. Two key approaches to internationalisation - internationalisation of curriculum (Internationalisation of Curriculum) (Knight, 2003) and internationalisation at home (Internationalisation at Home) (Nilsson, 2003) - are of particular importance for Allied Health degrees.

\section{Internationalisation of Curriculum and Internationalisation at Home - Definition, differences and issues}

Many authors have described Internationalisation of Curriculum (see for example, Leask (2005) but Knight's definition seems to be the most frequently cited. Knight (2003, p.2) defines Internationalisation of Curriculum at the national, sector and institutional levels as the process of integrating an international, intercultural, or global dimension into the purpose, functions or delivery of postsecondary education. For the purposes of this paper, Knight's definition of Internationalisation of Curriculum applies. Student mobility, typically achieved through international placements, and global health courses are popular means through which Internationalisation of Curriculum is achieved in health education (particularly in medical education). There is a misconception that international placements equal Internationalisation of Curriculum (De Wit, 2011). However, these opportunities may not be

\footnotetext{
${ }^{2}$ Work readiness is defined as the extent to which graduates possess the attributes that prepare them for success in the workplace (Caballero et al., 2011).
}

Nagarajan, S. \& Mc Allister, L. (2015). Internationalisation of curriculum: Imperatives, opportunities and challenges for allied health education. Journal of Teaching and Learning for Graduate Employability, 6(1), 88-99. 
core components in health degrees and hence there is no guarantee that they will be completed by all students or that learning outcomes will be assessed. Further, De Wit (2012) states that mobility is merely an instrument for promoting internationalisation and not a goal in itself (p.6). Therefore, simply studying or staying abroad is not equivalent to Internationalisation of Curriculum. For example, students visiting foreign countries could develop feelings of isolation and refrain from engaging with the locals due to either culture shock or uneasiness. It is important to evaluate all mobility experiences to understand if students have developed the intended international and intercultural perspectives (De Wit, 2011). Having a number of strategic partnerships with international institutions for staff and student exchange is also not equivalent to internationalisation. De Wit points out that all exchange activities and experiences of staff and students should be evaluated to understand if such experiences have resulted in the development of intended international and intercultural outcomes for the participants.

A conceptual framework for internationalising the curriculum (see Figure 1) has been developed by Leask (2012). This framework captures the multiple layers of interactions between curriculum design, content, pedagogy, learning tasks and assessment, and how these are influenced by broader issues such as institutional, local, national and regional and global factors. Leask (2009) states that development of intercultural competence should be a key outcome of any internationalised curriculum. The campus environment, culture, curriculum, teachers and student interactions in and outside of classrooms have a role to play in the internationalisation agenda.

\section{A conceptual framework of internationalisation of the curriculum}

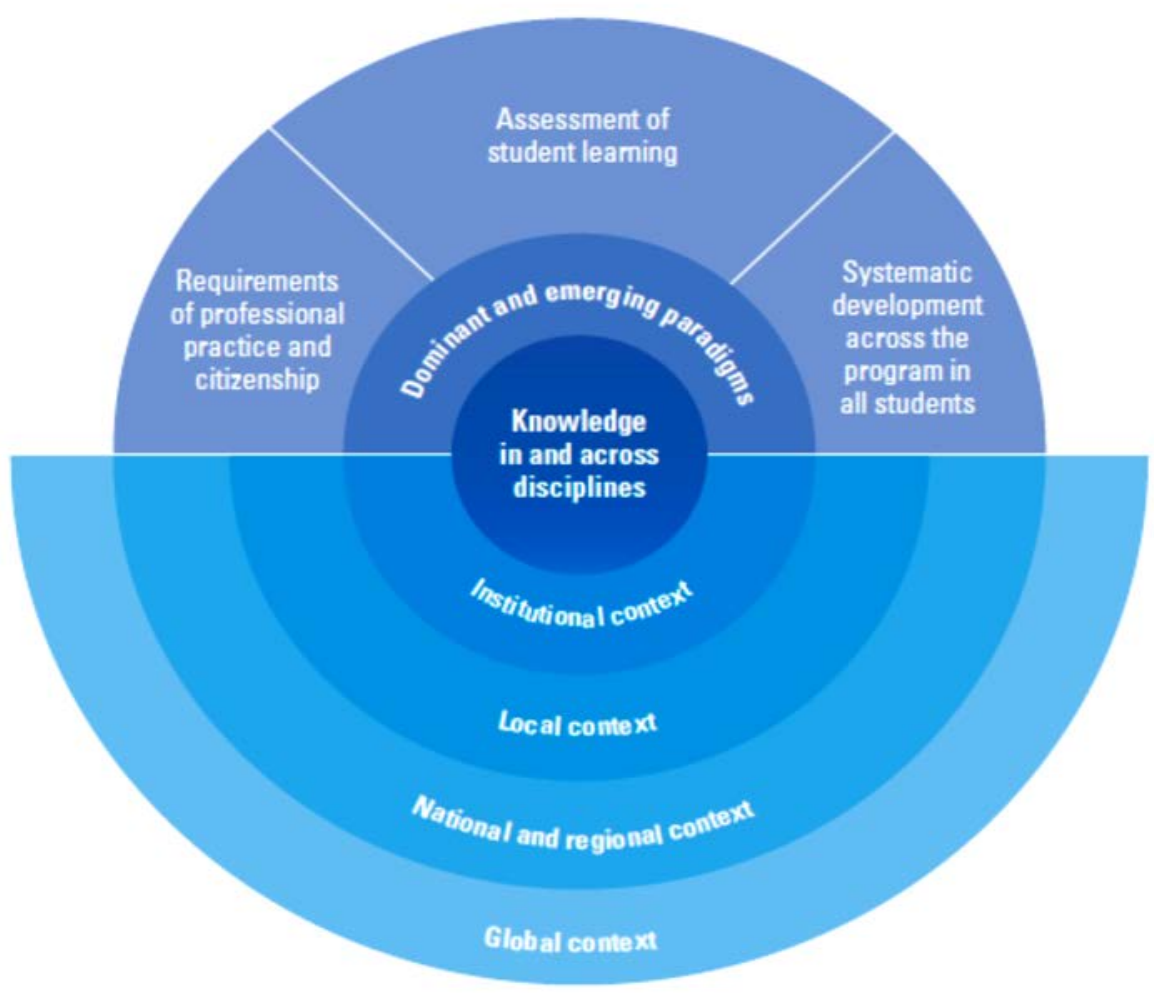

Figure 1: A Conceptual Framework of Internationalisation of Curriculum (Source: Leask, 2012) (Reproduced with the permission of Office for Learning and Teaching (OLT) 
Leask describes how both formal and informal curricula could be used as vehicles to develop intercultural competence through interactions between domestic and international students on campus. However, simply having a greater number of international students does not guarantee internationalisation (De Wit, 2011). There is evidence to suggest that there are many university programs where international students are seen as an isolated group (Leask, 2012). Leask also notes that providing opportunities for intercultural engagement alone is insufficient. She suggests these opportunities need to be facilitated so that the interactions between students from different cultures lead to meaningful contributions to the development of cross-cultural competencies in all students.

Another concept known as Internationalisation at Home has been discussed as an alternative to Internationalisation of Curriculum to overcome barriers of: a) limited mobility of students due to cost barriers associated with travel and living overseas and b) administrative challenges (including cost and risk management) for universities in ensuring international placement opportunities are available in a timely and safe manner for all allied health students. Nilsson (2003) refers to Internationalisation at Home as any internationally related activity with the exception of outbound student mobility (p. 31). Internationalisation at Home does not rely on student mobility. Instead internationalisation concepts and what Knight (2006) describes as a 'diversity of activities', (for example, using international case studies for learning and assessment, extracurricular activities, liaison with local cultural/ ethnic groups, and research or scholarly activities focussed on different approaches to issues in different countries) are embedded in the compulsory curriculum undertaken 'at home' with a specific focus to develop the international and intercultural competencies in all students (Leask, 2011). For the purposes of this paper, Leask's notion of Internationalisation at Home applies.

\section{Key examples of Internationalisation of Curriculum and Internationalisation at Home in disciplines other than allied health}

As part of her Office for Learning and Teaching (OLT) National Teaching Fellowship, Leask identified a number of papers reporting on Internationalisation of Curriculum in a range of disciplines (Office for Learning and Teaching, 2014). These are summarised in Table 1 as a prelude for considering the application of reported approaches to Internationalisation of Curriculum in allied health. Some disciplines featured in Table 1, such as medicine (Harden, 2006; McNicoll, Burney, \& Luff, 2006; Murdoch-Eaton, Redmond, \& Bax, 2011) and nursing (Calvillo et al., 2009; Mill, Astle, Ogilvie, \& Gastaldo, 2010) have a long history of internationalisation of the curriculum. Medicine relies mainly on overseas placements and global health courses (Stutz, Green, McAllister, \& Eley, 2014) for internationalisation of their curricula. Disciplines such as Accounting (Cobbin \& Lee, 2002; Evans, Tindale, Cable, \& Hamil Mead, 2009), and Law (Davies \& Shirley, 2007) have attempted to internationalise their curriculum using a variety of approaches as detailed in Table 1. As Table 1 shows, the Internationalisation of Curriculum and Internationalisation at Home (IAH) literature discusses the significance of internationalising curriculum (for example, using student mobility) and the challenges, but provides few studies on actual implementation of Internationalisation of Curriculum or Internationalisation at Home initiatives and evaluation of outcomes for students, faculties and universities. In particular, few studies exist on the impact of Internationalisation of Curriculum and Internationalisation at Home on graduate practice and graduate competencies (Lattanzi \& Pechak, 2012).

Nagarajan, S. \& Mc Allister, L. (2015). Internationalisation of curriculum: Imperatives, opportunities and challenges for allied health education. Journal of Teaching and Learning for Graduate Employability, 6(1), 88-99. 
Table 1: Approaches to Internationalisation of Curriculum in Various Disciplines*

\section{Discipline I Reference Context/Approaches used \\ Country}

$\begin{array}{ll}\text { Medicine } & \text { Murdoch-Eaton } \\ & \text { et al. (2011) }\end{array}$

UK

Murdoch-Eaton
et al. (2011)

Explores three pedagogic models for teaching Global Health: 1) an additive or contributory model of global health content (e.g., elective subject); 2) an integrated approach (some elements of global health teaching components are embedded within mainstream curriculum (e.g., utilisation of international tutors and visiting speakers to provide stimulus and share experiences across a range of cultural perspectives); 3) a transformative learning experiences approach requiring institutional and program flexibility (e.g., using international staff and students, patients/community, students recently returned from international placements as resources or as co developers of curricular material).

Medicine Harden (2006) Explores the use of a three-dimensional international medical graduate (IMG) model based on the interrelationship between student, teacher, and curriculum, unlike traditional model of medical education which involves a local teacher, a local student, and a local curriculum. The IMG model uses varying combinations of the three dimensions (e.g., international student, local teacher, and local curriculum). Information and communication technologies (ICT) tools (example, Videoconferencing using Skype) and e-learning provide support for virtual classrooms.

Medicine/ McNicoll et al. Reports on the Internationalisation of Curriculum project experiences of an Australian university's Faculty of Nursing and (2008) Medicine, Nursing and Health Sciences which attempted to internationalise the curricula of its 32 undergraduate and 76 postgraduate coursework programs. Initiatives such as consciousness-raising for academic leaders, professional development for academics, an offshore teaching guide and a resources website received considerable acceptance across diverse academic staff.

Australia

Nursing

Canada

Examines concepts related to global citizenship, globalisation, social responsibility, and professionalism in the context of nursing education. Argues that Internationalisation efforts must move beyond creation of international placement opportunities or the use of international examples within existing courses. Discusses the need for nurse educators to develop strategies and design innovative curricula to provide opportunities for all students to become engaged with the concept of global citizenship. 


\begin{tabular}{|c|c|c|}
\hline $\begin{array}{l}\text { Discipline I } \\
\text { Country }\end{array}$ & Reference & Context/Approaches used \\
\hline $\begin{array}{l}\text { Nursing } \\
\text { USA }\end{array}$ & $\begin{array}{l}\text { Calvillo et al. } \\
(2009)\end{array}$ & $\begin{array}{l}\text { Describes five cultural competencies for nursing students and provides suggestions for evaluation of students' } \\
\text { cognitive learning of cultural competence, and changes to students' values and belief systems as they gain } \\
\text { exposure to diversity. Provides recommendations for implementation (leadership commitment to cultural } \\
\text { competence, faculty development, and foreign-language requirements). }\end{array}$ \\
\hline $\begin{array}{l}\text { Accounting } \\
\text { Australia }\end{array}$ & $\begin{array}{l}\text { Cobbin \& Lee } \\
(2002)\end{array}$ & $\begin{array}{l}\text { Applies a curriculum analysis technique to undergraduate accounting subjects by auditing curricular elements } \\
\text { that are internationally relevant, Australia-specific and those that are specific to Australia but are transferable to } \\
\text { international contexts and makes recommendations for internationalising different subjects. }\end{array}$ \\
\hline $\begin{array}{l}\text { Accounting } \\
\text { Australia }\end{array}$ & $\begin{array}{l}\text { Evans et al. } \\
(2009)\end{array}$ & $\begin{array}{l}\text { Uses a collaborative teaching approach (involving discipline specialist and English language specialist) in } \\
\text { programs with diverse student populations to develop professional communication as a key aspect of accounting } \\
\text { programs. Recommends program level approach changes without compromise to technical content. }\end{array}$ \\
\hline $\begin{array}{l}\text { Science } \\
\text { Australia }\end{array}$ & Bell (2008) & $\begin{array}{l}\text { Describes a case study of a science course that involved student groups from three different countries using } \\
\text { videoconferencing for cross-institutional and international discussion. Discusses issues such as perceived } \\
\text { cultural differences in communication. }\end{array}$ \\
\hline Business & $\begin{array}{l}\text { Crosling et al. } \\
(2008)\end{array}$ & $\begin{array}{l}\text { Describes a case study of organisational change (process) involved in one Australian institution's attempts to } \\
\text { implement curriculum internationalisation in the foundation subjects in six core business disciplines. Factors that } \\
\text { need to be considered to enable curricular changes (academic workload, commitment from senior management) } \\
\text { during the internationalisation process are also described. Provides evidence for positive experience of staff and } \\
\text { students involved in the internationalisation project initiatives. }\end{array}$ \\
\hline $\begin{array}{l}\text { Law } \\
\text { Australia }\end{array}$ & $\begin{array}{l}\text { Davies \& Shirley } \\
(2007)\end{array}$ & $\begin{array}{l}\text { Describes an international work placement model for internationalising work integrated learning for law students } \\
\text { at an Australian university. A range of international employers were involved in the creation of virtual international } \\
\text { placement opportunities for students using ICT tools such as Skype, e-learning, learning management systems, } \\
\text { e-portfolios and specially designed activities. }\end{array}$ \\
\hline
\end{tabular}
specific.html 


\section{Internationalisation of Curriculum and Internationalisation at Home in allied health education}

\section{Literature search strategy}

It is significant that Leask's fellowship identified few examples of Internationalisation of Curriculum and Internationalisation at Home initiatives in allied health curricula.

As discussed later in this paper, much of the work in allied health to date has taken a narrow focus on the development of intercultural competency. A literature search on Internationalisation of Curriculum and Internationalisation at Home initiatives in allied health education was conducted using Google Scholar. The authors' familiarity with literature in the Internationalisation of Curriculum and Internationalisation at Home in allied health led them to believe that Google Scholar would be a useful search engine to search for the 'grey literature' such as the OLT project reports, conference proceedings, books and articles (Gray et al., 2012) and preprint papers on author's or organisation's websites.

It is acknowledged that Google Scholar has several disadvantages: not all articles returned in search results are truly scholarly or peer-reviewed (example, course manuals) and hence it is not an adequate tool for conducting systematic reviews (Boeker, Vach, \& Motschall., 2013). However, Google Scholar was a preferable option for searching the literature due to its breadth of coverage.

The five allied health discipline groups at the University of Sydney with whom the authors are currently engaged in internationalisation of their curriculum were selected for this literature search (Physiotherapy, Occupational Therapy, Speech Therapy, Exercise Physiology and Diagnostic Radiography). Several combinations of the following terms were used: internationalisation of the curriculum, allied health, speech therapy, speech pathology, physiotherapy, physical therapy, occupational therapy, diagnostic radiography, internationalization of curriculum, internationalisation of the curriculum, internationalization of the curriculum, internationalisation, exercise physiology, internationalisation at home. The search strategies employed looked for exact phrases with AND combinations for articles from the period 2000-2014 (for example, exact phrase 'Internationalisation at Home' AND 'physiotherapy' anywhere in articles published between 2000 and 2014 returned 17 results).

Where the results returned more than 100 articles (example, 'Internationalisation' AND 'Allied Health' returned 225 search results) the first 100 articles were opened and viewed to see if they had Internationalisation of Curriculum initiatives in allied health as the primary focus of the article. The majority of the resources that had used the search terms above did not on review have Internationalisation of Curriculum or Internationalisation at Home as the main topic of discussion. Only a few articles focussed directly on Internationalisation of Curriculum and Internationalisation at Home initiatives in allied health education (see Table 2). Some of these discussed the importance of internationalisation in allied health education while others discussed the need for development of internationalisation outcomes for allied health graduates. A small number of papers $(n=6)$ reported on Internationalisation of Curriculum initiatives undertaken in allied health (for example, Internationalisation of Curriculum initiatives in physiotherapy education at University of South Australia discussed in Das (2005).

\section{Discussion of the literature}

All the papers that discussed course level Internationalisation of Curriculum or Internationalisation at Home initiatives or approaches in an allied health related discipline are listed in Table 2. Table 2 also shows the skills and/or competencies in relation to internationalisation and the variety of tasks, activities and approaches discussed in these studies. Due to a paucity of Internationalisation of Curriculum and Internationalisation at Home 
literature in allied health a detailed discussion of studies that have occurred in allied health has been included in this section. Papers and project reports listed in Table 2 cover topics such as practical strategies internationalising curriculum within an allied health curriculum, student perceptions of internationalisation skills and their importance, achievement of Internationalisation of Curriculum using curriculum revisions, alignment of Internationalisation of Curriculum objectives and curriculum, development of intercultural competence curricular resources, use of ICT for advancing internationalisation outcomes and discussion of service learning as a potential opportunity for development of international perspectives of allied health students.

Horton (2009) proposed several ideas for internationalising occupational therapy education which included introduction of international themes or dimensions into teaching and learning and research. Practical strategies to internationalise the curriculum (see Table 2) were also presented, and Horton emphasised the need for financial, academic and administration support for successful implementation of the suggested strategies. Case studies in physiotherapy have used curriculum revision as an opportunity to address internationalisation as well as ICT tools and technologies to achieve internationalisation outcomes for domestic as well as international students. Das (2005) described a case study of the review of a physiotherapy program at University of South Australia to achieve a better alignment with their principles of Internationalisation of Curriculum that resulted in changes to curriculum which advanced cultural competence of their students and staff. Leask (2004) also discussed a case study of physiotherapy students at the same university where internationalisations outcomes were achieved simply by using ICT tools (see Table 2) to carry out some course activities/assignments that enabled student interactions with peers and external educators at overseas physiotherapy departments at various institutions.

Graduate perceptions of the importance of internationalisation skills were also studied. Useh's (2011) study explored physiotherapy graduates' perceptions of socio-cultural competence. Physiotherapists believed that socio-cultural competence included skills such as flexibility (ability to adapt to different situations), respect and awareness of differences in behaviour and attitude to health care, awareness of multicultural identity, cross-cultural awareness and stress management, empathy and foreign language proficiency. Empathy and flexibility was perceived by participants as highly important socio-cultural competence to be considered for inclusion in the physiotherapy course. Foreign language proficiency was considered as the least important aspect of socio-cultural skill for reasons such as participants not interested in working abroad and lack of availability of translators.

Pechak and Thompson (2010) and Lattanzi and Pechak (2012) discussed the notion of international service learning (ISL) as a possible approach to internationalisation of physical therapy education and use of ISL as a pedagogical tool. Seifer (1998) defines service learning as a structured learning experience that combines community service with explicit learning objectives, preparation, and reflection. When service learning occurs outside of the country where the education program is located it is referred to as ISL (Pechak \& Thompson, 2010). While the papers in Table 2 addressed Internationalisation of Curriculum or Internationalisation at Home, another body of research relevant to internationalisation skills and competencies for graduates focusses on cross-cultural and socio-cultural skills. Some terms commonly used to indicate skills and competencies that contribute to internationalisation outcomes for health graduates are cross-cultural, socio-cultural, international and intercultural skills.

A second group of papers addressing internationalisation in allied health learning and teaching were also identified. These papers focused on the development of cross-cultural skills and intercultural/cross-cultural competencies, understanding the social determinants of health and working in low resource environments, skills for working internationally; and the role of service learning in development of these skills. Studies with speech pathology, occupational therapy and physiotherapy students explored the experiences of clinical educators and students

Nagarajan, S. \& Mc Allister, L. (2015). Internationalisation of curriculum: Imperatives, opportunities and challenges for allied health education. Journal of Teaching and Learning for Graduate Employability, 6(1), 88-99. 
Table 2: Approaches to Internationalisation of Curriculum and Internationalisation at Home in Allied Health

Tasks/activities/approaches identified in the

referenced paper as contributing to Internationalisation

of Curriculum and Internationalisation at Home

\begin{tabular}{|c|c|}
\hline $\begin{array}{l}\text { Referencel } \\
\text { Disciplinel } \\
\text { Internationalisation } \\
\text { of Curriculum or } \\
\text { Internationalisation } \\
\text { at Home }\end{array}$ & Skills/attributes discussed in the paper \\
\hline $\begin{array}{l}\text { Horton (2009) } \\
\text { Occupational Therapy } \\
\text { Internationalisation of } \\
\text { Curriculum }\end{array}$ & $\begin{array}{l}\text { - } \text { Cross-cultural skills/competence } \\
\text { - } \quad \text { Culturally competent graduates } \\
\text { development (understanding of their own beliefs and values, } \\
\text { respect differences in beliefs or values across different } \\
\text { cultures), understand contextual implications of } \\
\text { internationalisation experiences to make a judgement about } \\
\text { how to apply that experience/evidence in their own clinical } \\
\text { contexts }\end{array}$ \\
\hline
\end{tabular}

\section{Internationalisation \\ at Home}

- $\quad$ Cross-cultural skills/competence

- Culturally competent graduates

Graduates who can utilise diversity development (understanding of their own beliefs and values, cultures), understand contextual implications of to contexts
- $\quad$ Reports on the introduction of international themes or dimensions into Teaching, Learning and Research

- Reports on the introduction of cross-cultural skills in curriculum, special classes such as language studies

- Encourages staff/students study/work abroad (needs financial, academic and administrative support) and engage in communication in an international work environment with people from different cultures

- Encourages access to skilled migrant groups, asylum seeker groups, refugees (depends on accessibility, support)

- Expand focus from local scenarios and clinical examples to international clinical training scenarios

- Socio-cultural competencies, Intercultural competence

Skills - flexibility, respect and awareness of differences in behaviour and attitude to health care, awareness of multicultural identity, cross-cultural awareness and stress management, empathy in a foreign language

Physiotherapy

Internationalisation of Curriculum
- Identifies challenge of lack of assessment tools to evaluate outcomes of internationalised curriculum which makes it difficult to measure progress and impact of internationalisation
- Intercultural competence (knowledge of cultural issues and other strategies that affect practice and develop ability to cope/deal with them; ability to work with people from different cultures, awareness of cultural barriers, cultural communication) 
Referencel

\section{Discipline}

Internationalisation

of Curriculum or

\section{Internationalisation}

\section{at Home}

\section{Lattanzi \& Pechak (2012)}

Physiotherapy

Internationalisation at Home

\section{Skills/attributes discussed in the pape}

- $\quad$ Being able to understand the relationship between social and economic determinants of health

- Developing understanding of globalisation of health and health care trends, practices that help/hinder quality of care delivered locally/internationally and

- Understand healthcare in low-resource settings (identify barriers to health in low resource settings locally and internationally, be able to work across cultures, understand culture and ethical issues in underserved population groups)
Tasks/activities/approaches identified in the

referenced paper as contributing to Internationalisation

of Curriculum and Internationalisation at Home

- Provides service learning opportunities with a local diverse community as one way to achieve Internationalisation of Curriculum objectives at home (Reynolds, 2005; Lattanzi \& Pechak, 2012)

- Uses integrated course content (includes public/global health content in an existing course) or dual degree pathways

- Uses ICT and technology applications (Skype, Webbased video conferencing, virtual collaboration for research assignments) to engage expert speakers/international partners from around the globe

- $\quad$ Provides students with opportunities for reflective practice that is, self-assessment and assessment of cultural competency

- Provides students with in-class activities about identifying barriers to health in different local and international settings, case studies on healthcare practices in low resource settings

Pechak \& Thompson (2010)

Physiotherapy

Internationalisation of Curriculum
- Considered programs in US/Canada that provided service learning

- Service-learning, clinical experience, cross-cultural experience, experiential learning, international cultural immersion international physiotherapy experience, study abroad
- Discusses service learning as an opportunity for developing cultural competence

$\begin{array}{lll}\text { Leask (2004) } & \bullet & \text { Intercultural perspectives } \\ & \bullet & \text { International perspectives } \\ \text { Physiotherapy } & \bullet & \text { Ability to work across national and cultural boundaries } \\ \text { Internationalisation at } & \text { - Ability to obtain ideas and use experiences from different parts } \\ \end{array}$

- Discusses an example case at University of South Australia (Williams \& Blaney, 2000) that used ICT tools and technologies for achievement of internationalisation outcomes in a health sciences course. Physiotherapy students used ICT tools (web 


\begin{tabular}{|c|c|c|}
\hline $\begin{array}{l}\text { Referencel } \\
\text { Disciplinel } \\
\text { Internationalisation } \\
\text { of Curriculum or } \\
\text { Internationalisation } \\
\text { at Home }\end{array}$ & Skills/attributes discussed in the paper & $\begin{array}{l}\text { Tasks/activities/approaches identified in the } \\
\text { referenced paper as contributing to Internationalisation } \\
\text { of Curriculum and Internationalisation at Home }\end{array}$ \\
\hline Home & & $\begin{array}{l}\text { and email) used to interact with international } \\
\text { educators to gather information regarding } \\
\text { assessment and management of a patient scenario } \\
\text { provided to them. Evaluation showed students } \\
\text { believed that this assignment enhanced their } \\
\text { understanding of international perspectives }\end{array}$ \\
\hline $\begin{array}{l}\text { Das (2005) } \\
\text { Physiotherapy } \\
\text { Internationalisation of } \\
\text { Curriculum (loC) }\end{array}$ & 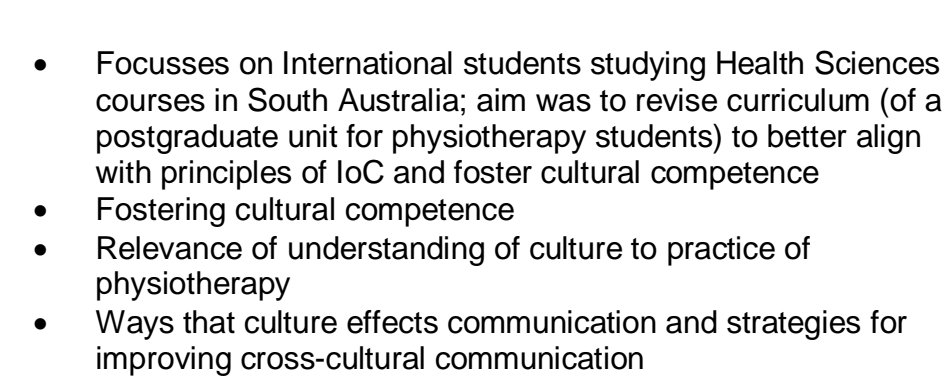 & $\begin{array}{l}\text { - Shift from viewing students as having gaps in skills or } \\
\text { understanding about Australian norms to fostering the } \\
\text { development of cultural competence that would } \\
\text { enable students to recognise cultural differences } \\
\text { between their home and Australian education as well } \\
\text { as healthcare systems } \\
\text { - Reflective practice used to revise course content and } \\
\text { assessment } \\
\text { Evaluation suggests cultural competence } \\
\text { advancement in both students and teachers }\end{array}$ \\
\hline $\begin{array}{l}\text { Mak \& Barker (2013) } \\
\text { Allied Health, Nursing } \\
\text { and Business } \\
\text { Internationalisation at } \\
\text { Home }\end{array}$ & $\begin{array}{l}\text { - Focusses on health (pharmacy, nursing and psychology) and } \\
\text { business. Aim was to internationalise learning and teaching } \\
\text { practices } \\
\text { - Intercultural capabilities or intercultural competence } \\
\text { - Internationalisation of teaching and learning practices }\end{array}$ & $\begin{array}{ll}\text { - } & \text { Fosters intercultural capacity building of students and } \\
\text { - } & \text { teachers } \\
\text { - } & \text { resourtable intercultural competence curriculum } \\
\text { - Develop cultural awareness of local and international } \\
\text { students }\end{array}$ \\
\hline
\end{tabular}


undertaking international fieldwork placements (McAllister \& Whiteford, 2008; Chipchase, Allen, Eley, McAllister, \& Strong, 2012) and studied the development of students' clinical reasoning skills in intercultural placements, cultural knowledge and intercultural competence. Studies in occupation therapy and physiotherapy education have also reported on academic and student perspectives on studying abroad (Deardorff, 2006; Kinsella, Bossers, \& Ferreira, 2008). More recently, a project (Mak \& Barker, 2013) funded through the Australian Government's Office for Learning and Teaching developed adaptable intercultural competence curriculum resources for health faculties, including psychology (see Table 2), with a view to internationalise learning and teaching practices at home institutions.

The literature review summarised in Table 2 shows that consideration of Internationalisation of Curriculum and Internationalisation at Home in allied health courses is limited. Horton (2009) calls for more research on how to use internationalisation strategies in occupational therapy education and to understand how such internationalisation can impact students' practice. The next section provides some ideas derived from the papers reviewed in this article for progressing Internationalisation of Curriculum and Internationalisation at Home in allied health education through formal and informal curriculum.

\section{Suggestions for progressing internationalisation of allied health curricula}

An internationalised curricula includes international and intercultural dimensions (Leask, 2009). This section provides some suggestions for allied health educators for internationalising their curricula. These suggestions are grounded in the preceding overview of internationalisation approaches in other disciplines and a summary of current internationalisation approaches in allied health. A list of key questions that needs to be considered by academic teams embarking on an Internationalisation of Curriculum process is described in detail in Leask (2012). Leask emphasises the need for these teams to engage in a cyclical process of conceptualising, planning, implementing, reflecting and evaluating programs and activities for internationalisation of curricula (see Figure 2). Leask also describes the important role of the institution as well as the discipline involved in the internationalisation of curricula. The institutional policies (for example, graduate attributes), international dimension in degrees offered (example, international languages offered as subjects within courses) and financial support for developing international teaching and

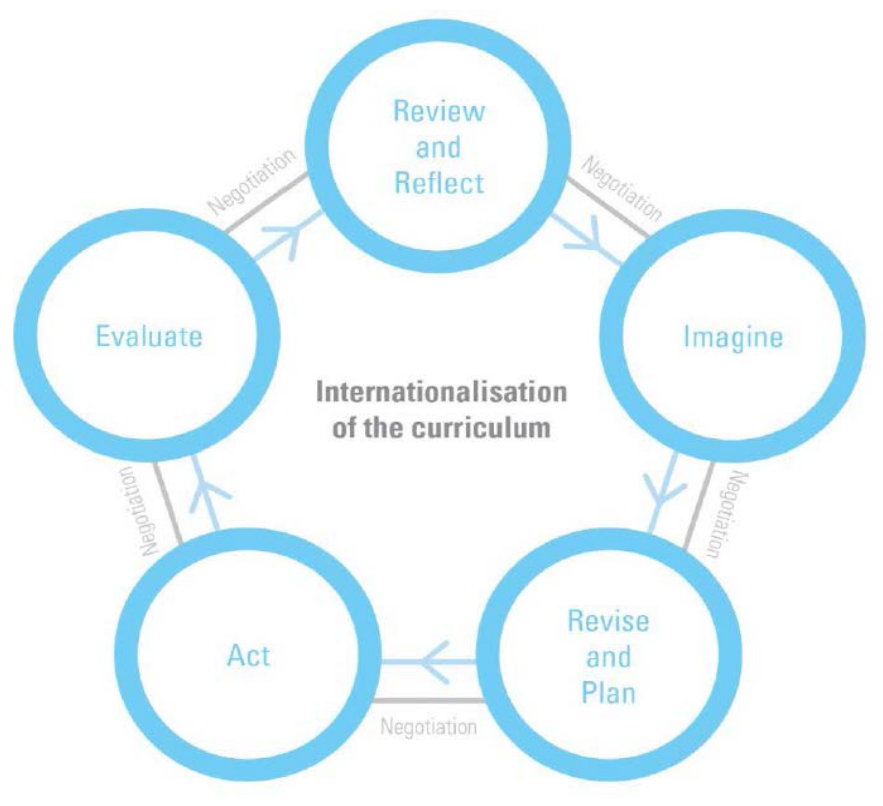

Figure 2: The Process of Internationalisation of Curriculum (Source: Leask, 2012)

(Reproduced with the permission of Office for Learning and Teaching)

Nagarajan, S. \& Mc Allister, L. (2015). Internationalisation of curriculum: Imperatives, opportunities and challenges for allied health education. Journal of Teaching and Learning for Graduate Employability, 6(1), 88-99. 
research collaborations to assist with staff and student development are enablers for internationalisation at an institutional level. The academics from the individual disciplines are the central actors in the internationalisation of the curriculum process as they are responsible for curriculum design, delivery and assessment. Academics need to consider how they can influence their institutions to create an environment that facilitates internationalisation.

Formal curriculum is defined as the stated, intended, and formally offered and endorsed curriculum while the informal curriculum is an unscripted, predominantly ad hoc, and highly interpersonal form of teaching and learning that takes place among and between faculty and students (Hafferty,1998, p. 404). Both Formal Curriculum (for example, subjects aimed at fostering an understanding of application of theory to different cultures and contexts such as developed, developing, underdeveloped countries) and Informal Curriculum (for example, enabling students to engage with migrant or refugee groups in the home country to provide different perspectives about health systems and practices in different countries) need to be carefully planned to provide opportunities for allied health students to develop international and intercultural perspectives.

\section{Leveraging the informal curriculum}

Maximising and using diversity in the university environment is one of the many ways to assist allied health graduates develop social and cultural skills. The diversity of staff and students who come from a range of ethnic and cultural backgrounds is under-utilised on campus as a resource for development of students' intercultural competence (Ho, Holmes, \& Cooper, 2004). Allied health education needs to consider ways to address common barriers to integration of domestic and international student cohorts such as language, cultural and social barriers, and previous life and educational experience of domestic and international students. In well-planned activities, international students could contribute diverse cultural perspectives and experiences to enrich those of domestic students (Leask, 2009). It has been suggested that encouragement of student interactions should be supported through a rewards system that recognises the importance of such interactions (Leask, 2009). Table 3 provides some ideas for leveraging informal curriculum opportunities.

\section{Table 3: Ideas for Internationalisation at Home - Leveraging Informal Curriculum Opportunities}

\section{Leveraging Informal Curriculum}

- Liaising with local cultural/ethnic groups (Garfinkle, 2007)

- Using migrant/refugee/ethnic groups in the home country to provide different perspectives (Lattanzi \& Pachak, 2012; Useh, 2011)

- Using diversity on campus to encourage cultural lunches, debates, competitions, mentoring (example, domestic students mentoring international students) (Leask, 2009)

- Buddies/mates programs, attendance and participation in cultural events on campus (Leask, 2009)

- Peer assisted study sessions, study support groups organised by teacher and student services support departments (Leask, 2009)

- intra and inter-university competitions, for example, the Healthcare Team Challenge (Richardson, Gersh, \& Potter, 2012)

- Encouraging allied health student volunteers to plan and conduct major events on campus and facilitating increased interaction between students from different cultures

Nagarajan, S. \& Mc Allister, L. (2015). Internationalisation of curriculum: Imperatives, opportunities and challenges for allied health education. Journal of Teaching and Learning for Graduate Employability, 6(1), 88-99. 
A further issue to consider when using informal curricula or co/extracurricular activities as means for the development of intercultural competencies is how to assess the development of such skills. If these co-curricular activities are not mandatory it is difficult to guarantee participation of all graduates and assess or measure achievement of outcomes (Leask, 2009). Harnessing the cultural diversity of campuses could be reflected in the formal curriculum by inclusion of appropriate assessment items.

\section{Leveraging the formal curriculum}

The literature suggests some key approaches for progressing Internationalisation at Home through formal curricula. These include cultural awareness and competency training, developing an understanding of different cultural approaches to healthcare, service learning placements, and project work. Cross-cultural competency development could be infused throughout the allied health curriculum in a range of ways. Embedding international case studies, assignments and utilising the cultural diversity available on campus through staff and students in teaching, learning, assessment and research activities are key to enhancing students understanding of healthcare in different countries and cultures. Additional suggestions are provided in Table 4.

\section{Table 4: Suggestions for Internationalisation of Allied Health Curricula - Leveraging Formal Curriculum Opportunities}

\section{Themes}

\section{Leveraging Formal Curriculum}

Student development

- Utilisation of international research and international students as informants for analysis and discussion of international health systems and perspectives (McAllister \& Whiteford, 2008) (e.g., Maximise the use of diversity in the student cohorts by forming learning pairs for assignments and rotating pairs (for example: pair a local student with an international student for assignments) or bring together students from different disciplines within the faculty to interact and collaborate with each other on assignments) (Leask, 2009)

- Engagement of students in research projects/assignments to analyse different approaches to issues in different countries (Leask, 2009).

- Inclusion of mandatory service learning placements in a different country or socio-culturally diverse settings at home (volunteer organisations, not for profit) (Reynolds, 2005; Lattanzi \& Pechak, 2012).

\begin{tabular}{|c|c|}
\hline $\begin{array}{r}\text { Curriculum } \\
\text { design, } \\
\text { learning } \\
\text { activities and } \\
\text { assessment }\end{array}$ & $\begin{array}{l}\text { - Discussion of application of theory to different cultures and contexts (developed, developing, } \\
\text { underdeveloped countries) (Horton, 2009) (e.g., Comparative studies of patient interventions } \\
\text { in home and other countries (Hanover Research Council, 2010)) } \\
\text { - Inclusion of multicultural or international views/perspectives (e.g., case studies) in allied } \\
\text { health subjects for both learning and assessment } \\
\text { - Development of cultural awareness through - discussion of cultural, language differences } \\
\text { and barriers, impact of language and culture, different culture/country based attitudes to } \\
\text { disadvantaged people, disabled persons (Horton, 2009) (e.g., Brainstorming of ideas and } \\
\text { strategies in-class to develop ability in students to cope with cultural as well as socio- } \\
\text { economic differences (Useh, 2011)) } \\
\text { Gathering of support from stakeholder groups such as the professional standards or board or } \\
\text { associations to formally recognise cross-cultural competency as a priority for graduate skill } \\
\text { development (McAllister \& Nagarajan, 2015). } \\
\text { Utilisation of perspectives of experienced allied health academics/clinical educators involved } \\
\text { in international collaborations and students undertaking fieldwork and study in international } \\
\text { placements to inform development of learning resources (such as testimonials, videos from } \\
\text { international placement experiences that could be used for on campus education). }\end{array}$ \\
\hline $\begin{array}{r}\text { Staff } \\
\text { development }\end{array}$ & $\begin{array}{l}\text { - Preparation of academics as international educators with ability to facilitate culturally diverse } \\
\text { student groups (McAllister \& Whiteford, 2008) } \\
\text { - } \quad \text { Provision of dedicated cross-cultural or cultural sensitivity training courses (Leask, 2009) }\end{array}$ \\
\hline
\end{tabular}

Nagarajan, S. \& Mc Allister, L. (2015). Internationalisation of curriculum: Imperatives, opportunities and challenges for allied health education. Journal of Teaching and Learning for Graduate Employability, 6(1), 88-99. 
Teaching, learning and assessment tasks may need to be redesigned to achieve real engagement between all students on campus. Innovative ways of teaching and learning could be considered, such as use of virtual classrooms with international mentors, international employers, and interactions with international experts or even student groups from different countries (Harden, 2006; Bell, 2008). This requires allied health educators to consider a shift from traditional ways to teaching and learning (for example, local teacher-local student-local curricula) towards contemporary ways of teaching and learning (example, local studentinternational teacher-international curriculum) (Harden, 2006), and to make structural changes to the curriculum to meet Internationalisation of Curriculum objectives. Assessment should test knowledge as well as action or demonstration of intercultural and international competencies (Leask, 2009).

Carefully planned informal and formal curricula will need to address a range of challenges to implement and integrate internationalisation goals in allied health curricula. These challenges have been identified in a range of disciplines and are summarised in the next section.

\section{Approaches to overcoming challenges for implementation and assessment of Internationalisation at Home in allied health}

Throughout the paper numerous challenges to Internationalisation of Curricula were signalled. In this section we discuss some key challenges: creating a shared understanding of nationalisation, a lack of studies focused on internationalisation in allied health, difficulties in measuring success for internationalisation learning outcomes and institutional barriers to developing curricula.

The lack of shared understanding of what internationalisation means was noted in the introduction. Comparison of Internationalisation of Curriculum and Internationalisation at Home studies is difficult because of lack of shared understanding of internationalisation concepts and terms. Describing, evaluating and assessing Internationalisation of Curriculum or Internationalisation at Home outcomes from different studies is challenging because studies do not use terminology and measures. This is also a barrier to gathering 'evidence' for impact of Internationalisation of Curriculum and Internationalisation at Home.

The Internationalisation of Curriculum approaches in allied health described in an earlier section demonstrated a range of terminologies to refer to skills and/or competencies in relation to internationalisation and a variety of tasks, activities and approaches that contributed to internationalisation goals. This diversity of terms and approaches presents challenges in comparing studies or understanding the development of skills and competencies for health graduates. An agreed framework and nomenclature would assist comparative research; the United Nations Educational, Scientific and Cultural Organisation (UNESCO) (2013) resource may provide such a conceptual and operational framework for intercultural competences. It provides steps that can be taken for clarifying, teaching, promoting, enacting and supporting intercultural competences.

A recent UK study (Ryall, 2014) investigated health sciences staff conceptions and experiences of internationalisation at a UK institution and indicates current understandings amongst teaching academics. Key findings were that: a) health sciences staff considered internationalisation as developing people's knowledge of global issues, growth in intercultural sensitivity and skills and the ability to see the wider picture and their position within it; b) internationalisation enhanced people's ability to cooperate and collaborate with each other and as a result adapt to a dynamic world; and c) the internationalisation process has stages of input, activities, output and outcome which are a complex but interlinked set of stages which are influenced by global, national, higher education and individual factors. More studies are needed to address a gap in knowledge about the disciplinary staff conceptions of the term internationalisation.

Nagarajan, S. \& Mc Allister, L. (2015). Internationalisation of curriculum: Imperatives, opportunities and challenges for allied health education. Journal of Teaching and Learning for Graduate Employability, 6(1), 88-99. 
The literature analysis presented in this paper indicates that there is a paucity of studies in allied health that focussed on the implementation of Internationalisation at Home (Useh, 2011). Although discussion of Internationalisation of Curriculum and Internationalisation at Home is well developed (Leask 2005, 2007, 2009, 2011, 2012) research on the implementation and assessment of Internationalisation at Home is still scarce. Many difficulties in evaluation of outcomes for students, faculties, university and community in relation to Internationalisation of Curriculum and Internationalisation at Home exist. However, some research in this direction is already starting to emerge. Recent studies in the broader internationalisation literature (Deardoff, Thorndike Pysarchik, \& Yun, 2009; Olsen, 2009; Jenkins-Deas, 2009) have started reporting on outcomes for individuals who have experienced Internationalisation of Curriculum or Internationalisation at Home. Currently there are no studies in allied health that examine the impact of Internationalisation of Curriculum or Internationalisation at Home initiatives on allied health graduates' practice. More research evidence regarding assessment of Internationalisation of Curriculum and Internationalisation at Home initiatives and their impact on allied health graduates' practice is essential.

There are also difficulties associated with measuring success in Internationalisation of Curriculum or Internationalisation at Home. For example, consensus and clarity regarding what indicators to measure, methods of measurement, and foci of measurement (inputs, outputs or outcomes) should be resolved before an institution embarks on measuring success of Internationalisation of Curriculum or Internationalisation at Home initiatives (De Wit, 2009). Some models for assessment of outcomes and impacts of internationalisation by using sample indicators for the assessment of Internationalisation of Curriculum have been reported in the literature (Hudzik \& Stohl, 2009). Sample indicators for the assessment of Internationalisation of Curriculum have also been reported in case studies (Hudzik \& Stohl, 2009). Learning inputs (for example, number of lecturers engaged in teaching with international or global content), outputs (for example, number of students enrolled in international or global majors), learning outcomes (evidence of students' capacities to work with others from different cultures) and a number of other indicators (for example, engagement inputs, outputs and outcomes) can be used for assessment of internationalisation (Hudzik \& Stohl, 2009). Recent studies have begun to systematically evaluate implementation and outcomes. Teissier (2007) reported a case study from Mexico which used an Internationalisation at Home model for institutional development across the entire institution at Universidad Regiomontana (UR). The Internationalisation at Home model at this university included elements such as internationalising the curriculum (introduced an Internationalisation of Curriculum process to all academics through workshops and support from Internationalisation of Curriculum experts), use of textbooks in a language other than Spanish, leveraging expertise of international visiting teaching staff and speakers, assessing linguistic ability of staff and students and ensuring an international ambiance and ethos on campus. Similarly, Leask (2007) described a case study of using diversity on campus in an Australian university to develop an institution wide approach to internationalisation. Key findings were that institutional policy, planning and public statements of support recognising the intellectual wealth which the diverse group of students and staff bring to the life of the university were an important aspect of internationalisation within an institution.

There are also challenges for universities as large institutions in embracing internationalisation. The time and expense involved in engaging all relevant stakeholders in the Internationalisation of Curriculum/Internationalisation at Home process along with a lack of funding, legal and administration support present obstacles to pursuing internationalisation goals in many institutions (Van Damme, 2001; Siaya \& Hayward, 2003; Adelman, 2004).

In this section some practical strategies for internationalising allied health curriculum are described. Universities and faculties need to consider allocation of dedicated resources to develop cultural awareness amongst their students. Strategies to introduce cross-cultural skills in curriculum, special classes such as language studies, encouraging staff/ students to study or work abroad need financial, academic and administrative support (Horton, 2009). Strong

Nagarajan, S. \& Mc Allister, L. (2015). Internationalisation of curriculum: Imperatives, opportunities and challenges for allied health education. Journal of Teaching and Learning for Graduate Employability, 6(1), 88-99. 
evidence justifying any investment in internationalisation initiatives is essential but is currently limited in literature.

\section{The future of internationalisation in allied health}

A review of the current literature and resources for internationalisation in allied health also provides directions for future effort. The main aim of a recent study (Mak \& Barker, 2014) funded by the Australian Government, Office for Learning and Teaching (OLT) titled, Internationalisation at Home: Enhancing intercultural capabilities of business and health teachers, students and curricula was to internationalise the learning and teaching practices of business and health education. Participating disciplines, pharmacy, nursing and psychology, implemented capacity building of academic staff, local and international students and development and implementation of intercultural competency curriculum tools and resources. One of the key recommendations for universities arising from this study was that the need to increase support and resources available for professional development on Internationalisation of Curriculum and Internationalisation at Home for academics and clinical placement supervisors. The recommendations and the curriculum resources developed as a result of this study are applicable to allied health more generally.

Internationalisation efforts in allied health are well placed to address many of the misconceptions identified by De Wit (2011). While there is a focus on increasing student mobility in allied health, participation rates are low and there appears to be recognition amongst academic staff that this alone does not equal internationalisation. More could be done to capture the learning outcomes from students on placements overseas and make these available more broadly to the student body through Internationalisation at Home initiatives, such as seminars from return students which are a required part of the curriculum for their student peers. There are large numbers of international students studying allied health degrees in Australia, and the degree requirements for the development of practical skills, in on-campus classes and on clinical placements where students are frequently placed in small groups, creates situations where international and domestic students mingle and learn with and from each other.

The nature of allied health practice brings allied health clinicians into daily contact with patients from diverse cultures and degree accreditation requirements include cross-cultural competencies for most allied health degrees. These are typically assessed on clinical placements where students can be expected to interact with patients from many cultures. While this aspect of Internationalisation at Home is already embedded and assessed in allied health curricula, allied health degrees could do more to systematically develop and assess competencies for practice in culturally diverse settings. Leask noted the importance of academic teams taking a cyclical approach to development, implementation and evaluation of efforts to internationalise curricula. Allied health already takes a holistic, cyclical approach to curriculum because accreditation requirements demand a whole-of-degree overview and tracking of knowledge and skills development. It would not be too great a step to include Internationalisation of Curriculum and Internationalisation at Home as curriculum foundation stones in allied health.

\section{Conclusion}

The importance of Internationalisation of Curriculum and Internationalisation at Home for allied health education is highlighted in this paper. A review of the literature suggests that discussion of Internationalisation of Curriculum and Internationalisation at Home is well developed in other disciplines but not in allied health. Several challenges to internationalisation for all disciplines including allied health were discussed. Existing frameworks for Internationalisation of Curriculum that allied health education could adopt were highlighted. Development of consensus on definitions and frameworks for Internationalisation of Curriculum and

Nagarajan, S. \& Mc Allister, L. (2015). Internationalisation of curriculum: Imperatives, opportunities and challenges for allied health education. Journal of Teaching and Learning for Graduate Employability, 6(1), 88-99. 
Internationalisation at Home will allow comparative research on internationalisation outcomes for all stakeholders. There is a need for all disciplines to research the implementation and outcomes at different levels. For example, robust research evidence is required in all disciplines to identify effective pedagogic and curricular responses for preparation of graduates capable of working in international contexts. Further, research on implementation and assessment of Internationalisation of Curriculum and Internationalisation at Home in most disciplines is still scarce. There is also a need for future research to focus on impact and outcomes arising from Internationalisation at Home initiatives. There is little evidence of impact of Internationalisation of Curriculum and Internationalisation at Home goals on allied health graduate employment or practice. Because it is coming relatively late to Internationalisation of Curriculum and Internationalisation at Home, allied health education has the opportunity to learn from other disciplines and ensure that its efforts in Internationalisation of Curriculum and Internationalisation at Home use consensus definitions and frameworks, are evidence based and incorporate evaluation of implementation and outcomes. Great opportunities exist for allied health to build internationalisation into formal curriculum because accreditation and registration requirements demand that skills such as cultural competence are formally included and assessed in curricula. The applied and practical aspects of clinical education lends itself to leveraging informal as well as formal curriculum. This paper identified some challenges for internationalisation of allied health education and raised important questions that should prompt academic, clinical educators and students to consider how well allied health education is addressing internationalisation goals and how these might contribute not only to graduate capabilities, but also to graduate employability. 


\section{References}

Adelman, C. (2004). Principal indicators of student academic histories in postsecondary education 1972-2000. Washington, DC: US Department of Education.

APTA (2014). The role of the physical therapist in national health care reform. Retrieved June 14,2014 , from http://www.apta.org/search.aspx?q=The\%20Role\%20of\%20the\%20Physical\%20Therapist \%20in\%20National\%20Health\%20Care\%20Rform

Bell, M. (2008). Internationalising the Australian higher education curriculum through global learning. Paper presented at the HERDSA 2008 Conference, Rotorua, New Zealand.

Boeker, M., Vach, W., \& Motschall, E. (2013). Google Scholar as replacement for systematic literature searches: Good relative recall and precision not enough. BMC Medical Research Methodology, 13(131), 1-12.

Caballero, C., Walker, A., \& Fuller-Tyszkiewicz, M. (2011). The work readiness scale (WRS): Developing a measure to assess work readiness in college graduates. Journal of Teaching and Learning for Graduate Employability, 2(2), 41-54.

Calvillo, E., Clark, L., Ballantyne, J. E., Pacquiao, D., Purnell, L. D., \& Villarruel, A. M. (2009). Cultural competency in Baccalaureate nursing education. Journal of Transcultural Nursing, 20(2), 137-145.

Chipchase, L., Allen, S., Eley, D., McAllister, L., \& Strong, J. (2012). Interprofessional supervision in an intercultural context: A qualitative study. Journal of Interprofessional Care, 26(6), 465-471.

Cobbin, P. E., \& Lee, R. E. N., (2002). A micro-journal approach to internationalising the accounting curriculum. Journal of Studies in International Education, 6(1), 59-77.

Crosling, G., Edwards, R., \& Schroder, B. (2008). Internationalizing the curriculum: The implementation experience in a faculty of business and economics. Journal of Higher Education Policy and Management, 30(2), 107-121.

Das, R. (2005). Internationalisation of the curriculum: Putting theory into practice in a physiotherapy program. Journal of University Teaching \& Learning Practice, 2(1), 25-35.

Davies, I., \& Shirley, M. (2007). Internationalising work-integrated learning for law students. Paper presented at the 15th World Conference on Cooperative Education (WACE), Singapore.

Deardorff, D.K. (2006). The identification and assessment of intercultural competence. Journal of Studies in International Education, 10(3), 241-266.

Deardorff, D., Thorndike Pysarchik, D., \& Yun, Z.S. (2009). Towards effective international learning assessment: Principles, design and implementation. In $\mathrm{H}$. De Wit (Ed.), Measuring success in the internationalisation of higher education (pp.23-38). European Association for International Education (EAIE), EAIE Occasional Paper no. 22.

De Wit, H. (2009). Measuring success in the internationalisation of higher education: An introduction. In H. De Wit (Ed.), Measuring success in the internationalisation of higher education (pp.1-8). European Association for International Education (EAIE), EAIE Occasional Paper no. 22.

De Wit, H. (2011). Internationalization misconceptions. International Higher Education, 64, 6-7.

De Wit (2012). Internationalisation of higher education: Nine misconceptions. In J. Beelen \& H. De Wit (Eds.), Internationalisation revisited: New dimensions in the internationalisation of higher education (pp.5-8).Centre for applied research on economics and management

Nagarajan, S. \& Mc Allister, L. (2015). Internationalisation of curriculum: Imperatives, opportunities and challenges for allied health education. Journal of Teaching and Learning for Graduate Employability, 6(1), 88-99. 
(CAREM), Amsterdam University of Applied Sciences, The Netherlands. Retrieved on December 3, 2015, from http://kennisbank.hva.nl/document/497769

Evans, E., Tindale, J., Cable, D., \& Hamil Mead, S. (2009). Collaborative teaching in a linguistically and culturally diverse higher education setting: A case study of a postgraduate accounting program. Higher Education Research \& Development, 28(6), 597-613.

Fuller, T., \& Scott, G. (2009). Employable global graduates: The 'edge' that makes the difference. Proceedings of the 18th Annual Teaching Learning Forum, 29-30 January 2009, Perth: Curtin University of Technology. Retrieved on October 18, 2010, from http://otl.curtin.edu.au/tlf/tlf2009/refereed/fuller.html

Garfinkle, A. (2007). Metro international: Creating local connections with the New York City community. In H. Teekens (Ed.), Internationalisation at home: Ideas and ideals (pp. 69-72). European Association for International Education, EAIE Occasional Paper no. 20.

Gray, J.E., Hamilton, M.C., Hauser, A., Janz, M.M., Peters, J.P., \& Taggart, F. (2012). Scholarish Google Scholar and its value to the sciences. Issues in Science and Technology Librarianship, Summer 2012. doi: 10.5062/F4MK69T9.

Hafferty, F. (1998). Beyond curriculum reform: Confronting medicine's hidden curriculum. Academic Medicine, 73(4), 403-407.

Hall, D. (2010). Internationalisation of the curriculum: Comparison and evaluation of definitions. Retrieved September 13, 2013, from http://www.google.com.au/url?sa=t\&rct=i\&q=\&esrc=s\&frm=1\&source=web\&cd=2\&cad=rja\& uact=8\&ved=0CCQQFjAB\&url=http\%3A\%2F\%2Ftne.curtin.edu.au\%2Flocal\%2Fdocuments \%2Fdefinitions internationalisation.pdf\&ei=UQrfU4XbH87k8AWXzILIBg\&usg=AFQjCNEXf XerT32GsGtDAgSIGRE3RI RJw

Hanover Research Council Report. (2010). Internationalization of the curriculum in higher education. Retrieved September 10, 2013, from

http://www.google.com.au/url?sa=t\&rct=i\&q=\&esrc=s\&frm=1\&source=web\&cd=1\&cad=rja\& uact $=8 \& v e d=0$ CBwQFjAA\&url=http $\% 3 \mathrm{~A} \% 2 \mathrm{~F} \% 2 \mathrm{Fw} w$ w. hu.ac.th\%2Fenglish $\% 2 \mathrm{Facademic} \%$ 2Fdocuments\%2FInternationalization\%2520of\%2520the\%2520Curriculum\%2520in\%2520 Higher\%2520Education\%2520\%2520Membership.pdf\&ei=6B7bU4zNIJe68gWg54CgDg\&u sg=AFQjCNHWJ01 IsSaiZo2KnjVL9NB2HIdLA

Harden, R.M. (2006). International medical education and future directions: A global perspective. Academic Medicine, 81(12 Supplement), 22-29.

Ho, E., Holmes, P., \& Cooper, J. (2004). Review and evaluation of international literature on managing cultural diversity in the classroom. Wellington: Ministry of Education and Education New Zealand.

Horton, A. (2009). Internationalising occupational therapy education. The British Journal of Occupational Therapy, 72, 227-230.

Hudzik, J.K., \& Stohl, M. (2009). Modelling assessment of the outcomes and impacts of internationalisation. In $\mathrm{H}$. De Wit (Ed.), Measuring success in the internationalisation of higher education (pp.9-22). European Association for International Education, EAIE Occasional Paper no. 22.

Jenkins-Deas, B. (2009). The impact of quality review on the internationalisation of Malsapina University-College, Canada: A case study. In H. De Wit (Ed.), Measuring success in the internationalisation of higher education (pp.109-121). European Association for International Education, EAIE Occasional Paper no. 22.

Nagarajan, S. \& Mc Allister, L. (2015). Internationalisation of curriculum: Imperatives, opportunities and challenges for allied health education. Journal of Teaching and Learning for Graduate Employability, 6(1), 88-99. 
Jones, E., \& De Wit, H. (2012). Globalization of internationalization: Thematic and regional reflections on a traditional concept. The International Journal of Higher Education and Democracy, 3, 35-54.

Kinsella, E. A., Bossers, A., \& Ferreira, D. (2008). Enablers and challenges to international practice education: A case study. Learning in Health and Social Care, 7(2), 79-92.

Knight, J. (2003). Updated internationalization definition. International Higher Education, 33, 23.

Knight, J. (2004). Internationalization remodeled: Definition, approaches, and rationales. Journal of Studies in International Education, 8(1), 5-31.

Knight, J. (2006). Internationalization of higher education: New directions, new challenges. International Association of Universities (IAU) $2^{\text {nd }}$ Global Survey report. Paris: IAU.

Lattanzi, J.B., \& Pechak C. (2012). Educating globally minded physical therapist students: Curriculum strategies to equip the next generation. Journal of Physical Therapy Education, 26 (1), 55-60.

Leask, B. (2004). Internationalisation outcomes for all students using Information and Communication Technologies (ICT's). Journal of Studies in International Education, 8(4), 336-351.

Leask, B. (2005). Internationalisation of the curriculum and intercultural engagement - a variety of perspectives and possibilities. Paper presented at the Australian International Education Conference, Gold Coast Convention and Exhibition Centre, October 11-14, Queensland, Australia.

Leask, B. (2007). Diversity on campus - an institutional approach: A case study from Australia. In H. Teekens (Ed.), Internationalisation at Home: Ideas and ideals (pp. 33-40). European Association for International Education, EAIE Occasional Paper no. 20.

Leask, B. (2009). Using formal and informal curricula to improve interactions between home and international students. Journal of Studies in International Education, 13(2), 205-221.

Leask, B. (2011). Internationalisation of higher education and internationalisation of the curriculum. Australian Learning and Teaching Council, Workshop Material.

Leask, B. (2012). Internationalisation of the curriculum in action. Fellowship Report, Office for Learning and Teaching: Australian Government. Retrieved September 1, 2013, from http://www.olt.gov.au/system/files/resources/Leask\%20UniSA\%20Fellowship\%20final\%20r eport\%202012.pdf

Lowe, S., Adams, R., \& O'Kanne, A. (2007). A framework for the categorization of the Australian health professional workforce. Services for Australian Rural and Remote Allied Health. Retrieved January 17, 2013, from http://www.sarrah.org.au/site/index.cfm?leca=283\&module=FILEMANAGER\&did=6547997 \&page category code $=6230 \&$ page $\mathrm{id}=98080$

Mak, A.S., \& Barker, M.C. (2013). Internationalisation at home: Enhancing intercultural capabilities of business and health teachers, students and curricula. Final report. Office for Learning and Teaching (OLT), Australian Government.

McAllister, L., \& Whiteford, G. (2008). Facilitating clinical decision making in students in intercultural fieldwork placements. In J. Higgs, M. Jones, S. Loftus \& N. Christensen (Eds.), Clinical reasoning in the health professions (pp. 357-365). ( $3^{\text {rd }}$ ed.) Elsevier.

McAllister, L., \& Nagarajan, S. (2015). Accreditation requirements in allied health education: Strengths, weaknesses and missed opportunities. Journal of Teaching and Learning for Graduate Employability, 6(1), 2-24.

Nagarajan, S. \& Mc Allister, L. (2015). Internationalisation of curriculum: Imperatives, opportunities and challenges for allied health education. Journal of Teaching and Learning for Graduate Employability, 6(1), 88-99. 
McNicoll, Y.R., Burney, S., \& Luff, A.R. (2008). Enhancing faculty culture to meet student needs: Internationalising the curriculum. Paper presented at the Australian Universities Quality Forum: Quality \& Standards in Higher Education: Making a Difference, 68-74, Canberra, Australia.

Mill, J., Astle, B., Ogilvie, L., \& Gastaldo, D. (2010). Linking global citizenship, undergraduate nursing education, and professional nursing: Curricular innovation in the 21st century. Advances in Nursing Science, 33(3), 1-11.

Murdoch-Eaton, D., Redmond, A., \& Bax, N. (2011). Training healthcare professionals for the future: Internationalism and effective inclusion of global health training. Medical Teacher, 33, 562-569.

Nilsson, B. (2003). Internationalisation at home from a Swedish perspective: The case of Malmö. Journal of Studies in International Education, 7(1), 27-40.

Office for Learning and Teaching (2014). IOC in action website - discipline specific literature. Office for Learning and Teaching (OLT): Australian Government. Retrieved September 24, 2014, from http://uq.edu.au/tediteach/OLT/resources-literature-discipline-specific.html

Oliver, B., Jones, S., Tucker, B., \& Ferns, S. (2007). Are our students work-ready?: Graduate and employer feedback for comprehensive course review. Paper presented the Evaluations and Assessment Conference, Brisbane, Australia. Retrieved October 15, 2011, from http://www.eac2007.qut.edu.au/proceedings/proceedings ebook.pdf

Olsen, A. (2009). Outcomes and impacts of international education on students. In H. De Wit (Ed.), Measuring success in the internationalisation of higher education (pp.93108). European Association for International Education, EAIE Occasional Paper no. 22.

Pechak, C., \& Thompson, M. (2010). Going global in physical therapist education: International service-learning in US-based programmes. Physiotherapy Research International, 16, 225236.

Reynolds, P.J. (2005). How service-learning experiences benefit physical therapist student's professional development: a grounded theory study. Journal of Physical Therapy Education, 19, 41-51.

Richardson, B., Gersh, M., \& Potter, N. (2012). Health Care Team Challenge: A versatile model for interprofessional education. MedEdPORTAL. Retrieved October 18, 2014 from: http://dx.doi.org/10.15766/mep 2374-8265.9287

Ryall, S.J. (2014). An investigation into the issues of staff's conceptions and experiences of internationalisation and the implications for its delivery in higher education. PhD Dissertation, University of Southampton.

Siaya, L., \& Hayward, F.M. (2003). Mapping internationalisation on US campuses. Washington, DC: American Council on Education.

Seifer, S.D. (1998). Service-learning: Community-campus partnerships for health professions education. Academic Medicine, 73 (3). 273-277. DOI: 10.1097/00001888-19980300000015.

Stütz,A., Green, W., McAllister, L., \& Eley, D. (2014). Preparing medical graduates for an interconnected world: Current practices and future possibilities for internationalizing the medical curriculum in different contexts. Journal of Studies in International Education. Published online June 26, 2014.

Teissier, C. (2007). Institutional development for Internationalisation at home: A case study from Mexico. In H. Teekens (Ed.), Internationalisation at Home: Ideas and ideals. European Association for International Education, EAIE occasional paper no. 20,.

Nagarajan, S. \& Mc Allister, L. (2015). Internationalisation of curriculum: Imperatives, opportunities and challenges for allied health education. Journal of Teaching and Learning for Graduate Employability, 6(1), 88-99. 
UNESCO (2013). Intercultural competences: Conceptual and operational framework (pp. 2332). United Nations Educational, Scientific and Cultural Organization. Retrieved January 18, 2014, from http://unesdoc.unesco.org/images/0021/002197/219768e.pdf

Useh, U. (2011). Internationalisation of higher education: Inclusion of socio-cultural skills in a physiotherapy programme. Journal of Human Ecology, 36(1), 1-7.

Van Damme, D. (2001). Quality issues in the internationalisation of higher education. Higher Education, 41(4), 415-41.

Williams, M., \& Blaney, F. (2000). Report on graduate quality exemplar. Adelaide: University of South Australia 